менше мотивації - кожен наступний крок посилює окреслене "порочне коло".

Спираючись на наведену аргументацію, автор аналітичної записки вважає за доцільне:

- Розробити та вести централізовану систему студентських опитувань.

- До розробки системи рекомендовано, окрім працівників 3ВО, активно залучати (круглі столи, обговорення тощо) зацікавлених студентів, студентське самоврядування. У процесі розробки власної системи варто спиратися на позитивний досвід міжнародних і вітчизняних ЗВО, наприклад систему студентських опитувань Українського католицького університету [5].

- Здійснювати комунікацію не лише зі студентами (чому саме їм вигідна система опитувань), а й із викладачами: акцент на об'єктивній фріксації їхніх кращих практик, можливості побачити себе збоку, поліпшити курси після відгуків, отримати премію (якщо місце в рейтингу викладачів, згідно з рішенням 3ВО, впливатиме на заробітну плату) тощо.

- Викладати проаналізовану інформацію у стислій та зрозумілій формі у відкритий доступ.

- Адміністрація обов'язково має реагувати на отриману інформацію.

- Упровадити широке медійне висвітлення реальних дій ЗВО на етапі "реакції" на офіційних каналах 3ВО: сайт та соцмережі ЗВО; соцмережі студентських парламентів.

- Системну проблему проведення студентських опитувань на рівні КНУ можна вважати вирішеною, коли: буде розроблена така система; половина від усієї кількості студентів буде проходити хоча б одне з опитувань (кількісні показники); результати опитування матимуть реальний вплив на проблеми (якісні показники) - тобто коли зазначена практика стане нормою у ЗВО.

\section{СПИСОК ВИКОРИСТАНИХ ДЖЕРЕЛ}

1. Звіт ректора Київського національного університету імені Тараса Шевченка за 2020 рік. [Електронний ресурс]. - Режим доступу: http://www.univ.kiev.ua/pdfs/zvit/zvit-rektora-2020.pdf

2. Опитування студентів філософського факультету щодо якості дистанційної освіти (станом на I семестр 2020-2021 н. р.). [Електронний pесурс]. - Режим доступу: https://drive.google.com/file/d/1pVdqtFXLWn RiOKZjK-XkqHyljEP_2FP4/view?usp=drivesdk
3. Результати опитування щодо якості освіти. Студентський парламент університету. [Електронний ресурс]. - Режим доступу: https://telegra.ph/Rezultati-opituvannya-shchodo-yakost\%D1\%96-osv\%D1\% 96ti-12-21

4. Рекомендації щодо застосування критеріїв оцінювання якості освітньої програми / Затверджено Національним агентством із забезпечення якості вищої освіти 17 листопада 2020 року - К.: ТОВ «Український освітянський видавничий центр "Оріон"», 2020. - 66 с.

5. Український Католицький Університет. Сектор моніторингу якості освіти. [Електронний ресурс]. - Режим доступу: https://academic.ucu.edu.ua/qa/

6. UNIDOS. Факультет соціології. Київський національний університет імені Тараса Шевченка. [Електронний ресурс]. - Режим доступу: http://unidos.univ.kiev.ua/?q=uk/pro_proekt

7. UNIDOS. Факультет соціології. Київський національний університет імені Тараса Шевченка. Звіт за 15 хвилею моніторингу 1 курсу та Звіт за 15 хвилею моніторингу 2-6 курсів. [Електронний ресурс]. - Режим доступу: http://unidos.univ.kiev.ua/?q=uk/zvity_pro_doslidzhennya

\section{REFERENCES}

1. Zvit rektora Kiïv'kogo nacional'nogo universitetu imeni Tarasa Shevchenka za 2020 rik [Rector's annual report for 2020. Taras Shevchenko National University of Kyiv]. Retrieved from http://www. univ.kiev.ua/pdfs/zvit/zvit-rektora-2020.pdf

2. Opituvannja studentiv filosofs'kogo fakul'tetu shhodo jakosti distancijnoï osviti (stanom na I semestr 2020-2021 n. r.) [Survey of students of the Faculty of Philosophy on the quality of distance education (first semester of 2020-2021 academic year)]. Retrieved from https://drive.google.com/file/d/1pVdqtFXLWnRiOKZjK-XkqHyljEP_2FP4/ view? usp=drivesdk

3. Rezul'tati opituvannja shhodo jakosti osviti. Students'kij parlament universitetu [The results of the survey on the quality of education. Student Parliament of the University]. Retrieved from https://telegra.ph/Rezultatiopituvannya-shchodo-yakost\%D1\%96-osv\%D1\%96ti-12-21

4. Rekomendacii shhodo zastosuvannja kriteriiv ocinjuvannja jakosti osvitn'oï programi [Recommendations for the application of the criteria for assessing the quality of the educational program]. (2020). Kyiv, Ukrainian Educational Publishing Center "Orion".

5. Ukraïns'kij Katolic'kij Universitet. Sektor monitoringu jakosti osviti [Ukrainian Catholic University. Education quality monitoring sector]. Retrieved from https://academic.ucu.edu.ua/qa/

6. UNiDOS. Fakul'tet sociologiï. Kiïvs'kij nacional'nij universitet imeni Tarasa Shevchenka [UNiDOS. Faculty of Sociology. Taras Shevchenko National University of Kyiv]. Retrieved from http://unidos.univ.kiev.ual ?q=uk/pro_proekt

7. UNiDOS. Fakul'tet sociologiï. Kiïvs'kij nacional'nij universitet imeni Tarasa Shevchenka. Zvit za 15 hvileju monitoringu 1 kursu ta Zvit za 15 hvileju monitoringu 2-6 kursiv [UNiDOS. Faculty of Sociology. Taras Shevchenko National University of Kyiv. Report on the 15th wave of monitoring of 1 st year students and Report on the 15th wave of monitoring of 2nd-6th year students]. Retrieved from http://unidos.univ.kiev.ual ?q=uk/zvity_pro_doslidzhennya

Надійшла до редколегії 15.04.21

D. K. Liashchenko, Student

Taras Shevchenko National University of Kyiv

60, Volodymyrska street, Kyiv, 01033, Ukraine

\title{
STUDENT SURVEYS: HOW TO TURN FORMALITY INTO OPPORTUNITY. CASE OF THE TARAS SHEVCHENKO NATIONAL UNIVERSITY OF KYIV
}

Д. К. Лященко, студент

Киевский национальный университет имени Тараса Шевченко,

ул. Владимирская, 60, г. Киев, 01033, Украина

СТУДЕНЧЕСКИЕ ОПРОСЫ: КАК ПРЕВРАТИТЬ ФОРМАЛЬНОСТЬ В ВОЗМОЖНОСТЬ. КЕЙС КНУ ИМЕНИ ТАРАСА ШЕВЧЕНКО

О. Ю. Павлова, д-р філос. наук, проф. Київський національний університет імені Тараса Шевченка, вул. Володимирська, 60, м. Київ, 01033, Україна invinover19@gmail.com

\section{ОгЛЯД ДИСКУсії "КУЛЬТУРОЛОГІЯ В УКРАїНІ": ЄДНІСТЬ У РІЗНОМАНІТТІ?", ЩО ВІДБУЛАСЯ ОНЛАЙН 30 БЕРЕЗНЯ 2021 РОКУ}

Дискусія стала спробою узагальнення та рефлексії щодо розуміння не лише предметного поля культурології загалом, переліку його актуальних проблем, але, насамперед, особливостей його становлення в Україні. Текст огляду відтворює не всі колізії розмови, але ті, що, на думку автора, зосереджувалися навколо наукових міркувань.

Першим виступив ініціатор Дмитро Шевчук, який сформулював основну ідею - розпочати дискусію про долю й особливості культурології в Україні. Він заува- 
жив, що "хоча такий вітчизняний варіант науки існував і раніше, але як освітня дисципліна народився в незалежній Україні. Після тридцяти років існування сформувались наукові осередки та школи. Протягом останніх років з'явились унікальні освітні програми. Настав час обговорити досвід становлення наукового й освітнього виміру культурології в Україні та створити мережу взаємодії, яка б допомогла це робити регулярно. Спонукала до такої пропозиції участь в експертній комісії Національного агентства із забезпечення якості вищої освіти, через що виникла необхідність усвідомлення та узагальнення, як кожний з вітчизняних університетів розуміє культурологію. Така дискусія не може бути однією, $є$ потреба розтягнути її в часі. А також створити колективну монографію з назвою цієї дискусії або тією, що з'явиться в ході дискусії".

Олена Павлова (Київський національний університет імені Тараса Шевченка) зазначила, що "брак часу передбачає тезисне і провокативне формулювання проблеми. Дискурс гуманітарних наук, починаючи 3 їхнього фрілософського витоку, $€$ західноцентричним. Іншим не може бути стиль та шлях української культурологічної думки 3 її історичною орієнтацією на європейську інтеграцію. У логіці протистояння імперському спадку та монополії на дискурс у Радянському Союзі, його надмірній ідеологічній навантаженості в українській культурі, а також у рефлексії щодо неї відбулася консервація форм високої культури у двох вимірах: раціоцентричний дискурс і художній образ. Претензія на автономність останнього була певною мірою опозицією до логоцентризму, але все одно в межах гегемонії високої культури. Тому всі форми культури і навіть їі рецепції в радянський і навіть пострадянський період здійснювалися і здійснюються в цій колізії. I не можуть її подолати.

Водночас логіка культурних досліджень загалом і Cultural studies Бірмінгемської школи зокрема в другій половині $\mathrm{XX}$ ст. постулює необхідність подолання таких крайнощів. Здійснюється критика редукції культури, з одного боку, лише до ціннісної сфери, а з іншого, лише до соціальних умов, у яких певні культурні феномени виникають.

Українська культурологічна думка демонструє вихідний зв'язок з послідовністю етапів розуміння культури в європейському центрі світ-системи: від надмірної романтизації пошуку джерел та "винайдення традиції" (Е. Гобсбаум) до "культурного повороту" на засадах критичної теорії. Власне, потрібно починати з розуміння цивілізації як високої культури, тобто з логіки троїстої диференціації, що була обґрунтована І. Кантом як автономність науки, моралі та мистецтва, і найбільш яскравим виявом західноцентризму (Н. Еліас і Р. Сеннет), модерного режиму сигніфікації (С. Леш). Винайдення власного шляху протистояння імперським традиціям науки й освіти $€$ особливістю вітчизняних культурних досліджень загалом. Важливу роль опозиції у вітчизняному варіанті здійснення й усвідомлення специфіки модерного режиму сигніфікації відіграє художнє поле, яке $€$ найбільш наочним виявом Модерну (як форми високої культури) й анти-Модерну (у логіці протистояння образа - тексту).

Закономірність й особливість становлення культурологічної думки в КНУ імені Тараса Шевченка виявилися в тому, що філософська думка в Радянському Союзі була однією з небагатьох дозволених форм культури, що спеціалізувались на рефлексії щодо ідеологічного змісту пануючого дискурсу зокрема та колізій соціокультурного розвитку. Так само художньому полю в радянському варіанті модернізації надавали певні преференції, що дозволяли навіть якоюсь мірою (дуже до- зованою) вийти за межі офіційної артикуляції смислів. 3 огляду на це філософські дисципліни, і насамперед естетика, мали певні переваги та свободу ширшого переосмислення досвіду культуротворення, а також потужну методологічну базу.

Виробництво культурних інститутів та тиражування культурної продукції радянською владою здійснювалися, передусім, у логіці організації високої культури, зокрема у вимірі художнього поля та закладів, що його обслуговують. I насамперед література, що є формою не лише сфери мистецтва, але й класичної культурної індустрії, потребувала відтворення, зокрема фахівців, що його забезпечують, не тільки як поле виробництва, але й тиражування (поліграфія), а також сфера комунікації з колом споживачів (бібліотекознавство). Зважаючи на це, найбільш численними закладами освіти, що зараз стали епіцентрами інституалізації культурології, були в радянські часи ті, що готували кадри для політичної освіти, культурно-освітньої роботи та бібліотечних фондів. На відміну від цього філософський дискурс та традиція його викладання на факультеті в Київському університеті - це була найбільша міра свободи творчості та університетської автономії, яку ми зберігаємо і культивуємо і нині.

Сучасний пафос подолання абсолютизації форм високої культури, що виразив Р. Вільямс (culture is ordinary), є зрозумілим. Проте кидатися в іншу крайність також $є$ небезпечним. Оскільки поза формою інституалізації функціонування багатьох культурних практик неможливо і тепер. Особливо без фахової підготовки, навіть для дедиференційованих сфер культури. 3 огляду на це рух сучасної культурологічної думки має бути обережним і поміркованим, на мою думку.

Особливу увагу слід приділяти трансформації культури та базовим тенденціям розвитку культурних досліджень. Лише в цьому контексті можна зрозуміти своєрідність української культури й особливості становлення вітчизняної культурологічної думки. Визначну роль у цьому процесі, я вважаю, відіграє оптика дисциплінарного поля Visual studies. Його методологічна й організаційна значимість полягає в тому, що саме цей спектр досліджень фіксує і являє собою стратегічні форми подолання домінації форм високої культури: тексту і художнього образу (зокрема підстав їхньої опозиції), панування дискурсу "лінгвістичного повороту" та мистецтвознавства в гуманітаристиці XX ст.

Викладання української культури традиційно відбувалося у класичному руслі: складалося з корпусу знань з історіографії й обов'язкового параграфу про мистецтво наприкінці. Своєрідність української культури зводилася до своєрідності українського мистецтва. Отже, відбувалося нехтування інтеграційним потенціалом культури в цілому та оптикою культурних досліджень зокрема. Visual studies з їхніми різноманітними блоками дисциплін нині $€$ епіцентром методологічної та організаційної критики редукції культури до дискурсоцентричних і художніх форм на засадах творення цілісного образу культури загалом та її носія Homo pictor".

Поставив запитання Дмитро Шевчук: "Специфіка інституалізації культурології в Київському університеті Тараса Шевченка полягає в утвердженні свободи філософського дискурсу через поєднання художнього компоненту та філософського?"

Олена Павлова відповіла, що "це більше той спадок, який залишився від радянських часів, був адекватний духу часу і мав тоді великі, насамперед методологічні переваги для розуміння поля культурології. Тепер ми намагаємося і рефлексувати над ним, і зорієнтуватися, 
як рухатися від нього далі в логіці організації та осмислення сучасного етапу української культури".

Максим Карповець запитав: "Visual studies $€$ виходом із домінування філософського, лінгвістичного та мистецтвознавчого дискурсу. Проте чи зможе ця дисциплінарна сфера випрацювати свою власну методологію, відмінну від зазначених видів дискурсу? Це поштовх для роздуму про предмет сфери культурології, особливо української? "

Олена Павлова відповіла, що обговорення трансформації гуманітарного дискурсу в нашому університеті проходить у дискусії з філософами. Вони всі як мантру повторюють про кризу і необхідність нової оптики й онтології. Культурологічні дослідження пропонують обидва елементи, зокрема розуміння нових історичних варіантів культурних практик і підстави переосмислення динаміки наповнення суб'єкт-об'єктної опозиції змістом того типу ієрархії культурних практик, яка є домінуючою на даний момент. Зважаючи на це, візуалізація $є$ настановою сучасної культури не лише тому, що вона $є$ дегуманізацією в тому сенсі, про який говорили на початку XX ст., а вириває 3 антропологічних параметрів здійснення переважну більшість культурних практик, оскільки вони здійснюються більшою мірою через порядок технізованих оптичних медіа, за їхньою логікою, а не на засадах співмірності людському тілу. Це спричинює зовсім іншу антропологічну модель. Саме в цьому полягає натепер автономність і навіть законодавчість принципів і предмета культурології.

Микола Зайцев (Острозька академія) погодився 3 тим, що "існують програмні предмети, що називаються культурологією. Проте чи існує українська культурологія? Дійсно, майже всі підручники з історії закінчувалися параграфом про мистецтво. I досі багато в чому розуміння культури залишається таким. Це зумовлено значною мірою тим, що сама культура, як зазначав М. Бахтін, не має своєї території. Іншими словами, не має чітко окресленого свого предмета. Ми працюємо у своїх курсах від поняття "культура". У всіх, якщо нас опитати, воно буде різне. 3 мистецтвом, його теорією й історією ми навчилися працювати, особливо з його окремими видами. Однак, якщо ставити питання, як Межуєв: що робить предмет культурою? Наприклад, роман Булгакова "Майстер і Маргарита" був закінчений разом із життям письменника 1940 р., але став явищем культури лише в шістдесяті роки. До того був твір літературний, але культурним став, коли почав осмислюватися та входити в культурне поле, набагато пізніше. 3 огляду на це ми маємо визначити першу проблему предметне поле культурології. Зараз воно розмите.

По-друге - окреслити смисловий горизонт культури. Також не можна в культурі бачити лише щось позитивне. У роботі О. Лосєва по епосі Відродження $є$ параграфр "Побутові типи Відродження", де він аналізує діяльність сімейства Борджіа, герцога Феррари. Там творилося те, що ми ховаємо від публічності. Ми згадуємо лише Леонардо та Шекспіра, хоча попередньо зазначені персони теж були титанами думки. Зі світлим завжди стоїть і темне. Ми не маємо уникати нічого. Це теж культура.

Наступний необхідний пункт - це структури культури. Ми рухаємося звичним шляхом. Можна, на мою думку, відштовхуватися від схеми культури, що була запропонована українським дослідником В. Нестеренком (Інститут водного господарства, м. Рівне).

Культурологія - це певне наукове небуття, оскільки, як сфрормулював Г.Гегель, буття та ніщо виявляють істину свою у становленні. Статус культурології - це ані буття, ані ніщо, але становлення, тому це не ми не розібралися з культурологією і масою речей у ній, але вона сама такою є за своєю природою.
На завершення про проблеми культурології не як дисципліни, а як науки. Насамперед, про культурологічний вимір взаємодії України з Європою. Це абсолютно темна пляма. Зазвичай розглядають економічний та політичний вимір взаємодії, а це дуже важлива і болюча проблема. Далі, як у культурі відбувається трансформація смислів та символів? Це питання вимагає дослідження, а також відносини філософії та культури".

Поставив запитання Дмитро Шевчук: "Миколо Олександровичу, ви були від початку становлення культурології в Острозькій академії. На що вона орієнтувалась при виникненні і на що зараз орієнтується? "

Микола Зайцев відповів, що "кафедра культурології та фрілософрії намагалася виходити з розуміння культури, яке було випрацюване в Київській антропологічній школі, - як способу колективного буття й індивідуального існування людини у світі. Чи вдалося нам реалізувати таке визначення? Дещо вдалося. Але багато в чому є над чим працювати. У нас чітко проведена межа між теорією та історією культури. Намагаємося реалізовувати фрілософрський підхід до розуміння культури саме в дусі Київської антропологічної школи. Хоча це не так уже і легко".

Поліна Гречанівська (Національна академія керівних кадрів культури і мистецтв) зауважила, що "культурологія на кафедрі культурології й інформаційних комунікацій НАКККіМ з'явилася 2014 р. Тут ми зіткнулися 3 тими проблемами, що обговорюються на нашій зустрічі. У межах однієї кафредри зустрілися представники різних шкіл культурологічних, з різними уявленнями і підходами. Антропологічна школа Університету Шевченка (В. Сіверс), Харківська культурологічна школа (я її представник), прикладна культурологія та івенткультурологія (О. Копієвська), ціла низька мистецтвознавців, істориків мистецтва. Кожне наше засідання кафедри перетворювалося на семінар 3 обговорення предмета культурології. Це спонукало нас визначити ОНП третього рівня для докторів філософії як "Теоретичні засади культурології". Тут ми присвячуємо багато уваги методології та понятійному апарату культурології, іiї предметному полю, демаркації предметного поля культурології з іншими галузями знань. Крім цього, із групою колег ми працюємо над виробленням освітніх стандартів з культурології. Уже затверджені стандарти бакалаврського і магістерського рівня, дебатуємо щодо стандартів рівня доктора філософії. У нашому закладі працює і голова підкомісії з менеджменту соціокультурної діяльності. Ми весь час дебатуємо про демаркацію поля дослідження прикладної культурології і менеджменту соціокультурної діяльності, де там пролягає межа. Де межа, що відділяє мистецтвознавство та історію мистецтв, а також їхня відмінність від предмета і завдань культурології. Усі ці питання є хвилюючими і потребують зосередження уваги. Проректор нашої академії виступив з ініціативою створення Ліги культурологів України, що буде підґрунтям таких починань, як сьогодні. Це передбачає об'єднання зусиль і співпрацю на спільному полі. Ми маємо ухил у бік вивчення музикознавчої культурології, культурології, пов'язаної з проблемами хореографії, проблемами релігійного мистецтва, фрілософії, з аналізом текстів і літературознавством. Об'єкт дослідження в нас може бути спільним 3 мистецтвознавством чи істориками культури, але водночас фрілігранне застосування культурологічної методології дозволить нам певне розуміння та відпрацювання спільної термінології, те, що формує ядро культурологічних досліджень".

Олена Молодина запитала: погоджуєтесь ви з тим, що процес розгортання культурології $€$ послідовним, об'єктивним, розгорнутим у часі?

Поліна Гречанівська відповіла, що "можу погодитись. Зокрема, я не поділяю песимізму Олександра Васильо- 
вича, що за тридцять років культурологія не змогла визначитися й інституалізуватися достатньо. Саме те різнобарв'я, різноманіття шляхів, якими науковці потрапляють в культурологію, - це прекрасно. Кожен привносить певні барви в ту палітру, якою є сучасна культурологія. Фактично багатство сучасних дискурсів обумовлено тим, що прийшли люди з різних дисциплін. Наприклад, історики мислять процесуально, мають розуміння принципів періодизації. Філософи привнесли свій понятійний апарат, збагатили мову культурології. Мистецтвознавці, етнографи, літературознавці, фахівці з музичного мистецтва, які мають досвід усвідомлення вузьких сфер культури і мистецтв, теж збагачують культурологію. Поєднання емпіричного матеріалу і досвід глибинного узагальнення і формують специфріку культурології".

Олександр Кравченко (Харківська державна академія культури) зауважив, що "у 1987 р. у Харківському інституті культури на той час амбітний декан (тепер ректор) очолив і кафедру теорії та історії культурнопросвітницької роботи. Він порушив до певної міри канони і неписані правила, що існували на той час, - почав укомплектовувати кафедру випускниками інших закладів. Так сталося, що це переважно були випускники історичного факультету Харківського університету. Зрозуміло, що виник внутрішній академічний конфлікт. Це була реперна точка. У 1988-1989 рр. визріла освітня альтернатива. Нам дістався курс - "Основи марксистсько-ленінської теорії культури". 1989 р. була остання всесоюзна нарада, присвячена ідеологічній кризі гуманітарних дисциплін у системі вищої освіти. Її наслідком став дозвіл викладати теорію й історію культури, а також уводити культурологію. Лобістами такої реорганізації стали представники інститутів культури: Московського, Ленінградського і Харківського. 1990 р. Харківський інститут здійснив набір викладачів училищ. Почали викладати історію та теорію культури. 3 історією було легше нам як історикам. 3 теорією було важче. Не йшлося про філософію культури, яку ми сприймали окремо та самостійно. Також не говорили про соціологію, тому що тоді ще фактично не було соціології в Україні. Важливим було позитивно переосмислити меседжі марксизму. Потім зникла кон'юнктура зовнішня і, на жаль, це все в зародку загубилося.

Наступний епізод. У 2005-2006 рр. група трохи в іншому складі, але ядро те саме, ініціювала новий процес, що завершився достатньо успішно. Це процес внесення культурології як окремої галузі в перелік наукових спеціальностей. Це завершилося 2007 р., коли виникли ті паспорти спеціальностей, якими ми нині послуговуємося. На жаль, декілька паспортів, що були розроблені і вважалися на той час інноваційними, зникли. Виник конфлікт із мистецтвознавцями й етнологами. Ті чотири паспорти, які залишилися, є кістяком наукової культурології в Україні.

Культурологія існувала як альтернатива. Вона мала стати сферою науково-освітнього спротиву, стати гіппі в гуманітарному середовищі. Вийшло так, що за тридцять років (я відраховую від 1990) культурологія перетворилася $з$ гіппі на гіпстерку. Ми виправдовуємо її інфантильність і сконструювали для цього цілу міфологію. Ми шукаємо корені культурології в інших проєктах. Зазвичай західних, які нам подобаються. Сьогодні можна сказати, що це постмодерний проєкт. Але я хочу, щоб ми не втратили і фундаментальної пострадянськості. Як в будові, структурі, так і функціях. Сталося як сталося: паспорти ніхто не читає. Багато років культурологія зникає в наукових текстах. Нині ми стали заручниками інституалізації культурології. Вона стала не джерелом епістемічних викликів, але обросла ракушняком академічних статусів. Стає притулком академічних маргіналів, не позбавляючись залежності від старших братів і сестер на кшталт фрілософії, історії тощо. Вони розглядаються як постачальники методів і методик. Культурологія набула офріційного статусу, але не позбавилась дитячих ілюзій щодо власної значимості. Це надія все ж таки не безвідмовна, оскільки існує соціальне замовлення. Хоча вона не набула наукової актуальності, а стала кон'юнктурним, вигідним адаптером бюрократичних новацій, що відбуваються в різні часи. Виконує фактичну функцію, яку виконувала марксистсько-ленінська теорія культури, проти якої ми колись повставали. Якщо почитати тексти міністрів культури чи освіти України в різні часи, то вони всі покладали на теорію та історію культури ідеологічні сподівання. На жаль, але це так. Також культурологія існує (є розуміння) як екстравагантна, неформальна практика, як грантова діяльність.

Підсумовуючи, можна сказати, що це - інклюзивна сфрера творчості. Це навіть не система знань. 3 невизначеним об'єктом. Предмет завжди визначений, а об'єкт ні. Кон'юнктурною методологією, часто запозиченою, тобто немає власного методу. Досить розмитими $є$ критерії науковості. На жаль. Мені важко говорити про унікальність культурологічних текстів. Якщо говорити про оригінальність зусиль, ми мали би говорити про загальне тло. Спільне - те, що нас поєднує, але дає можливість розрізнити. На мою думку, ми різні настільки, наскільки ми персонально різні, не схожі. Питання має бути поставлено радикально: чи є взагалі те, що ми називаємо українською культурологією? Є культурологія в Україні, але це певний спадок, з одного боку. А з іншого боку, спроба імпорту наукового. Будь-які інновації запозичені ззовні, вони передусім потрапляють у цю нішу, оскільки вона доволі маргінальна.

Говорити про школу і можна, лише маючи певний status quo, тому що ми прив'язані до закладів. Якщо видалити імена і прізвища 3 тих робіт, що пишуться, чи розпізнаємо ми, звідки вони, до якого закладу чи школи належить ця робота. Здається, ні.

Якщо говорити про больові точки, я би зосередився на трьох. Бракує дискурсу. Ми співіснуємо, але нечасто перетинаємося. Немає дискусії, немає про що говорити. Немає конфлікту, немає того, з чого починалася будьяка культурологія. Немає серйозних дискусій. Я маю на увазі серйозні дискусії - не просто на яких презентувалися проєкти, а обговорювалися по суті. Якісь ідеї, концепції, роботи, які мають реальні результати, які зачіпають певне коло дослідників, які бачать їх як своє. Тому що немає об'єкта дослідження, яке можна було б назвати культурологічним. Він завжди приписаний. Будь-що можна назвати в контексті культури. I це буде сприйматися як пас до культурології, але насправді це нікого ні до чого не зобов'язує. Саме це є проблемою, оскільки метод, про який ми говорили, є в проєкті. Тому і культурологія $€$ в проєкті. Мабуть, на щастя. Тому що $€$ надія, що культурологія все ж таки виникне.

Тематика дійсно може бути широкою. На мій погляд, проблема $є$ у тому, що тематика не приводить до якихось теоретичних рефлексій. Зазвичай констатується, що це танці, це театр, це музика. I наче те, що було, було в певному контексті культури. Звідси не виникає новація теоретична. Тому застій в теорії культури $є$ очевидним. І до певної міри культурологія залишається риторичною. Якщо прибрати з культурології історію фрілософрії, що в ній залишиться? Тобто ми риторично відтворюємо якісь штампи запозичених термінів і понять.

У такому випадку, мені здається, що вихід може бути. Він є. I це вихід в реальну практику дослідження. Не відтворення штампів, не перевірку теорій, які вмерли давно. А перейти від міфрологізації культурології до реальної оцінки того, що є. 3 рефлексії очевидно може вийти нова точка зростання". 
Олена Павлова запитала, як можна визначити консенсус істориків і фрілософів в межах харківської традиції культурології.

Олександр Кравченко відповів, що "базовий меседж не в тому, що все пропало, а слід навести оптику і відповісти, де ми знаходимося. Зрозуміло, що не може бути так, щоб всі роботи, що проводяться, були взірцевими і рівноцінними. Питання в тому, чому ті чи інші роботи автори вважають культурологічними. I відповідь на це питання не може бути кон'юнктурною. Я не цензор і не можу сказати, що знаю, як треба. Я лише можу, як і всі, перебувати в пошуку. Мають бути авторитети, під авторитетом я маю на увазі позицію, з якою можна солідаризуватися, що викликає резонанс загальнонауковий.

Щодо співвідношення теорії та історії культури. Історія культури існує спокійно і без культурології. Я займався історією Балкан як історик, а не культуролог. Але ми замислювалися так: чи стане історія культури культурною історією. Це сталося в західному проєкті, але, на жаль, не сталося в Україні. Я розумію культурологію як метанауку, тобто наднауку і в цьому сенсі не зовсім науку".

Оксана Дарморіз (Львівський національний університет імені Івана Франка): "Питання сьогоднішньої дискусії ми ставимо собі дуже давно. Лише у Львові $€$ п'ять освітніх програм з культурології.

Наша культурологія виникла на кафедрі теорії та історії культури. Спочатку вона була загальноуніверситетською, але після акредитації 2002 р. вона стає кафедрою при філософсському факультеті. По суті, вона і виникла як відгалуження фрілософрії, фрілософії культури, фрілософрської антропології. Уже на той час на кафедрі була сформована потужна база викладачів і культурологічних дисциплін. Історія і фрілософрія - це дві таких потужних складових. Тепер маємо і культурологів. Постійно намагаємося зрозуміти, що ми читаємо, як ми маємо читати свої курси. Потужна теоретична база допомагає нам це робити. Практичні завдання ми намагалися втілити через практики. Тепер уводимо і практичні дисципліни. Окремим питанням $€$ проблема комунікації між окремими культурними осередками.

Ми зрозуміли, що спільно простіше виробляти розуміння напрямків, якими можна керуватися. Проблемне поле культурології дуже широке, і це надає нам можливість для вибору різних дисциплін.

У Львові є громадська організація, що має назву "Українська асоціація культурологів - Львів". Тут активно працюють всі кафедри, які випускають культурменеджерів, менеджерів мистецтва та культурологів.

Західна культурологія існує набагато довше. Українська традиція ще має викристалізуватися".

У підсумку дискусії було зазначено Оксаною Дарморіз, що важливо продовжувати дискусію в ширшому предметному полі.

Олександр Кравченко підкреслив, що "необхідно розмежувати наукову й освітню проєкцію культурології. Вони і так існують автономно. Необхідно конкретизувати бачення предметних полів: теоретичної та практичної культурології, менеджменту соціокультурної діяльності, а також культурної антропології, мистецтвознавства і таке інше. Тобто нам потрібно уточнити не міждисциплінарні, а субдисциплінарні підходи. Основою для такої розмови є необхідність десакралізації культури. Стандарти освіти з нашої спеціальності можуть стати однією з тем для дискусії".

Поліна Гречанівська зазначила, що акредитаційна робота активізувала процес комунікації та спонукала до теоретичної рефлексії над освітньою й науковою трансформацією поля культурології. Обговорення має бути вільне від певних організаційних та інституційних завдань, а тому воно стане ґрунтовнішим.
Микола Зайцев підсумував, що розмова йшла про предмет культурології, зокрема "необхідно чітко окреслити її освітні та наукові межі".

Олена Павлова звернулася до тези П. Бурдьє, який стверджував, що "узгодження практик потребує практик узгодження. Автономізація культурних практик науки й освіти можлива лише до певної міри. Оскільки гуманітарні науки - це процес вироблення дискурсу, а освіта гуманітарна - це вироблення виробників дискурсу, що можливо лише у спільному полі з виробництвом дискурсу. I складність багатьох гуманітарних наук (мистецтвознавства, фрілософії, тією мірою, якою вона є наукою) полягає у тому, що предмет і метод корелюють, тобто оптика бачення залежить від ракурсу погляду. Складність культурології зростає: вона претендує бути інтегративною наукою. Постає питання, як бачити всезагальне, та ще і не філософським способом. Проте всезагальне завжди представлене через особливе. I це особливе і є способом візуалізації ієрархії культурних практик. Зазначене розуміння зумовлює оптику, через яку культура виявляє себе. Візуальні дослідження на сучасному етапі намагаються охопити єдність видимого і невидимого наявної ієрархії через не протиставлення образу та тексту, але через їхню інтеграцію.

Пані М. Гоц говорила про оптику соціальної антропології. Однак ми бачимо, що і поле соціології не $є$ стабільним. Воно здійснює зсув від соціології взагалі до соціології культури та культурної соціології, яку Дж. Александер конкретизує в логіці сильної методологічної програми в ракурсі теорії іконічної влади. Усе це певною мірою здійснюється на засадах дедиференціації соціального і культурного".

Дмитро Шевчук пообіцяв розробити програму зустрічей та уточнити тематику дискусій.

Як підсумок огляду дискусії можна зауважити, що у процесі обговорення стала зрозумілою наявність двох вимірів становлення культурології в Україні: організаційного й наукового.

Організаційний вимір успішно існує. Оскільки генеза культурології здійснювалася в контексті інституалізації освітніх процесів, то зміст наукового дискурсу культурних досліджень був похідним від констеляції освітніх програм тих закладів вищої освіти, що стали епіцентрами такої інституалізації. Цим визначається кількість і статусність тих наукових середовищ, що стали суб'єктами створення свого варіанта освітніх програм та інших форм акумуляції культурного капіталу (журналів, наукової та навчальної літератури, наукових рад із захисту дисертаційних досліджень, баз науково-освітніх практик, наукових і культурних проєктів). Особливу роль у формах самовизначення предметного поля відіграв перелік певних наук i спеціальностей, а також статус їхніх представників. Специфіка рецепції західної культурологічної думки визначається більше не інституалізаційними завданнями науки, а смаковими уподобаннями окремих представників. У цьому контексті базовим питанням стало, наскільки важливим $є$ розмежування освітніх і наукових вимірів культурології для розуміння її поля.

Науковий вимір дискусії зафіксував коло питань, що були найбільш чітко сформульовані:

- Наскільки репрезентативною є предметна невизначеність культурології щодо динамічної й інтегративної природи самої культури?

- Як співвідношення субдисциплін (теоретична, прикладна культурологія, менеджмент соціокультурної діяльності тощо) культурних досліджень виражає цілісність і різноманітність самого поля, обумовлює особливості не лише предметної сфери, а і його методологічних настанов?

- Як співвідносяться в культурології теорія та історія культури? Наскільки гегелівський принцип єдності 
історичного та логічного є значимим для зазначеної сфрери? Як уточнити завдання культурної історії на засадах рецепції української історії культури та досвіду рефлексії щодо неї?

- Що є критерієм того, що організація та систематизація різноманіття емпіричного матеріалу мистецтвознавства, фольклористики, етнографрії та інших субдисциплін виводять їх на рівень предметної ссрери та методології культурології як науки?

- Наскільки проблема співвідношення виробництва та споживання/рецепції визначає перетворення твору мистецтва в явище культурного продукту?
- Що є підставою редукції наук про культуру лише до сфери цінностей, до форм високої культури, до переліку позитивних взірців історії?

У правильно сформульованих питаннях міститься половина відповіді на них. Наступні дискусії мають давати відповідь в логіці розвитку європейського стилю наук про культуру, які не можуть бути втиснуті у прокрустове ложе пояснення (базове для природничих наук за В. Дільтеєм), але мають орієнтуватися на методологічну настанову розуміння. Водночас необхідно продовжувати традиції вивчення української культури, фундовані М. Максимовичем, М. Костомаровим, М. Драгомановим й ін.

Надійшла до редколегії 13.04.21

Е. Ю. Павлова, д-р филос. наук, профр.

Киевский национальный университет имени Тараса Шевченко, ул. Владимирская, 60, г. Киев, 01033, Украина

\section{ОБЗОР ДИСКУССИИ "КУЛЬТУРОЛОГИЯ В УКРАИНЕ": ЕДИНСТВО В МНОГООБРАЗИИ?", КОТОРАЯ ПРОШЛА ОНЛАЙН 30 МАРТА 2021 ГОДА}

O. Y. Pavlova, Doctor of Philosophical Sciences, Professor

Taras Shevchenko National University of Kyiv

60, Vladimirrvska Str., Kyiv, 01033, Ukraine

REVIEW OF THE DISCUSSION "CULTUROLOGY IN UKRAINE: UNITY IN DIVERSITY?", WHICH TOOK PLACE ONLINE ON MARCH 30, 2021

К. Р. Радик, студ. Київський національний університет імені Тараса Шевченка, вул. Володимирська, 60, м. Київ, 01033, Україна rom.and.kate@gmail.com

\section{МИСТЕЦТВО ПОЗА ІЗОЛЯЦІЕЮ}

Коли в розмові зачіпають тривожну і хитку тему посткарантинного майбутнього, хто-небудь неминуче озвучує ідею "світ ніколи не буде колишнім". Із цим важко посперечатися, проте в такому випадку потрібно було оголошувати паніку раніше: світ мав змінитися і без карантину.

У розділі "Обставини, що сприяють утворенню нових форм за допомогою природного відбору" усім відомої книги Ч. Дарвіна "Про походження видів" [1] розкривається актуальна нині ідея про те, що умови ізоляції можуть стати не просто вигідними, а навіть бажаними для трансформації біологічних видів: ізоляція надає можливість (насамперед - ресурс часу) для повільного саморозвитку. Приказка "тихіше їдеш - далі будеш" з одним тільки доповненням - їхати потрібно на самоті - несподівано виявляється рецептом успішності навіть для такої серйозної речі, як еволюція.

Соціальне дистанціювання стає новою нормою: незабаром наближення до співрозмовника на відстань менше півтора метра отримає тавро поганого тону. Подібна практика небезпідставно наштовхує на думку про те, що дистанціювання вплине і на сферу культури. На період карантинів наше культурне дозвілля має приблизно такий вигляд: 3D-тури музейними експозиціями, перегляд вистав у записі і домашні вечірки під трансляцію концертів у YouTube. Усе це підводить до висновку про майбутнє культури: мистецтво із цього дня входить в еру медіумів фото-, відео- та комп'ютерної графріки, викидаючи пензлі і фарби як непотріб, у той час коли артінституції дружно переходять на практику онлайну. Частково це дійсно правда - хоча варто розуміти, що фрарби та полотна нікуди не зникнуть, - але не карантин тому причина, а вже давно розпочата технічна революція.

У першій половині XX ст. в дослідженнях культури з'являється нова проблематика - тиражування мисте- цтва, автентичність відтворюваних робіт і значення технологій для художньої культури. 3 появою, наприклад, ідей В. Беньяміна про масовість мистецтва, яке позбавляється унікальності внаслідок численного тиражування, але набуває можливості широкого поширення у суспільстві, - ми дедалі більше говоримо про креативні індустрії і все менше - про культуру як таку [1]. Пандемія коронавірусу винна в одному: вона прискорила прихід майбутнього.

Ми можемо взяти на себе сміливість стверджувати, що мистецтво передбачило сучасну ситуацію. Смисли й ідеї, що створюються художниками, неодноразово апелювали до питань кордонів людського і технологічного, акторно-мережевої теорії, теорій суспільства ризику і біополітичного контролю. Недарма жанри дістопії (від класики світової літератури, роману "1984", до касового фрільму "Голодні ігри") десятиліттями користуються популярністю у книго-, ігро- та кіноіндустрії. Мистецтво нібито вже давно і наполегливо натякає: поява коронавірусу не зовсім випадкова.

Задовго до сьогоднішніх подій арткритик А. Шенталь опублікував "пророче" есе, присвячене френомену ізоляціонізму в культурі. У ньому він розкриває позитивні наслідки, здавалося б, абсолютно негативного процесу: на його думку, досвід відчуженості необхідний будьякому амбітному мистецтву [3]. Радянський ізоляціонізм, наприклад, свого часу став причиною появи московського концептуалізму і соц-арту. Якщо взяти будьяку картину, написану в цей період на території СРСР, то переплутати 3 роботами європейських модерністів того ж часу іï буде неможливо. Обмеженість, насамперед інформаційна, вимикає будь-яку рефлексію, і внаслідок цього мистецтво має надто наївний вигляд. Хyдожники соц-арту чинили з ідеологізованим мистецтвом 